\title{
AGGRESSIVE PROGRESSION OF TAKAYASU'S ARTERITIS IN INFANCY: A CASE REPORT
}

\author{
Roman Pavić ${ }^{1,2}$, Robert Blažeković ${ }^{1,3}$, Dalibor Divković ${ }^{1,4}$, Ksenija Marjanović $^{1,5}$ and Mirna Sipl $1^{1,6}$ \\ ${ }^{1}$ Faculty of Medicine, Josip Juraj Strossmayer University of Osijek, Osijek, Croatia; \\ ${ }^{2}$ Department of Traumatology, Sestre milosrdnice University Hospital Centre, Zagreb, Croatia; \\ ${ }^{3}$ Department of Surgery, Dubrava University Hospital, Zagreb, Croatia; \\ ${ }^{4}$ Department of Pediatric Surgery, Osijek University Hospital Centre, Osijek, Croatia; \\ ${ }^{5}$ Department of Pathology and Forensic Medicine, Osijek University Hospital Centre, Osijek, Croatia; \\ ${ }^{6}$ Department of Pediatrics, Osijek University Hospital Centre, Osijek, Croatia
}

\begin{abstract}
SUMMARY - Takayasu's arteritis (TA) affects the aorta and its branches. Immunosuppressants are the usual course of therapy, while surgery has been used in acute cases. There is only scant information on TA in infancy, and the nonspecific symptoms in the initial stage of the disease make the diagnosis difficult and delayed, thus increasing the mortality rate. We describe a case of aggressive progression of TA in an infant. This child was the youngest to be affected with the disease as reported in the literature. A 3.5-month-old boy presented with cyanosis of both legs, tachycardia and antithrombin III deficiency. Computed tomography angiography (CTA) revealed thrombosis of distal aorta and both iliac arteries. Thrombectomy was performed at the level of both common femoral arteries. In addition, thigh amputation of the left leg had to be performed. TA was diagnosed postmortem with thrombosis of the distal aorta, its branches and upper mesenteric artery which was not occluded on previous CTA, glomerulonephritis and pulmonary parenchymal granulomatous infiltrations.
\end{abstract}

Key words: Takayasu arteritis; Infant; Thrombosis; Immunosuppressive agents; Case reports

\section{Introduction}

Takayasu's arteritis (TA) is an inflammatory and stenotic disease of medium- and large-sized arteries and is characterized by predilection for the aortic arch and its branches ${ }^{1}$. TA has been associated with streptococcal infections, rheumatic fever, tuberculosis, rheumatoid arthritis, and other immune mediated conditions ${ }^{2}$; however, precise pathogenesis is unknown. Usually TA affects young women, most often been reported in young East Asian women (median age at onset, 25 years), in their second and third decades of life, and the age at onset is usually between 15 and 30

Correspondence to: Prof. Roman Pavic, $M D, P h D$, Department of Traumatology, Sestre milosrdnice University Hospital Centre, Draškovićeva 19, HR-10000 Zagreb, Croatia

E-mail: romanpavic29@gmail.com

Received July 7, 2016, accepted October 22, 2018 years ${ }^{1,3}$. However, the age at onset may vary from infancy ${ }^{1,4-8}$ to middle age. Although TA can affect both sexes and all races, women with TA outnumber men by 8-9:1 ${ }^{1}$. A similar gender predilection has been observed in various reports on children, with a femaleto-male ratio of $2: 1^{1,9,10}$. The incidence of TA is estimated to 2.5 per million people in the United States and 1.3 per million people in Europe ${ }^{1,3}$.

Clinical features of TA are divided into the early pre-pulseless systemic stage and late occlusive stage. Approximately half of all patients are difficult to diagnose in the early stage characterized by nonspecific features such as low-grade fever, malaise, night sweats, weight loss, arthralgia and fatigue $e^{1,11}$. This active stage may resolve spontaneously in about 3 months or may progress insidiously into the chronic stage characterized by inflammatory and obliterative changes in the aorta and its branches ${ }^{1,3}$. In this late occlusive stage of 


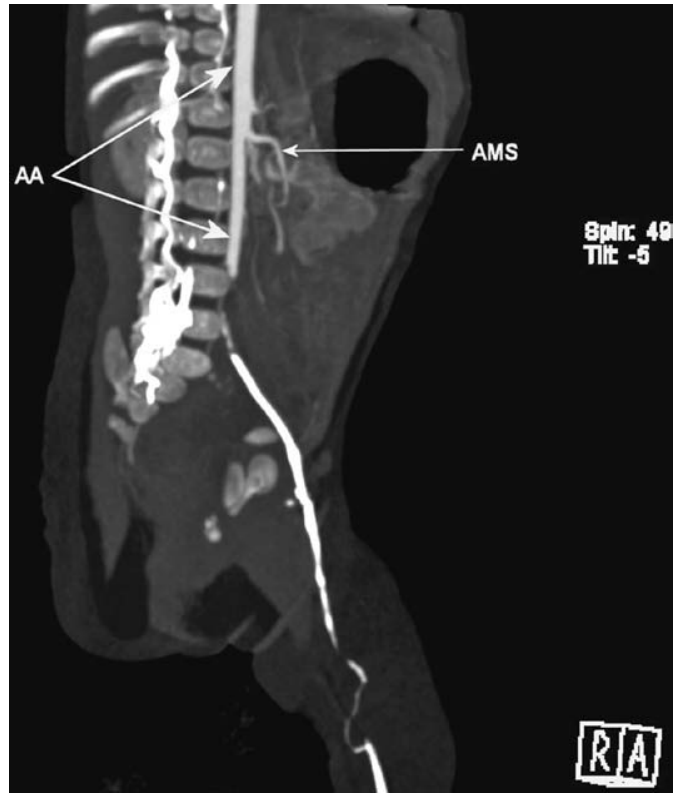

Fig. 1. Blood flow interruption at the level of distal aorta just below the origin of the inferior mesenteric artery; upper mesenteric artery at the time of performing computed tomography angiography imaging.

$\mathrm{AA}=$ abdominal aorta; $\mathrm{AMS}=$ upper mesenteric artery

the disease, characteristic features of TA appear, which include diminished or absent pulses, vascular bruits, hypertension (as a consequence of renal artery stenosis), mesenteric angina, retinopathy, aortic regurgitation (when the ascending aorta is involved) and neurological symptoms secondary to hypertension or ischemia (postural dizziness, seizures, amaurosis) ${ }^{1}$. Hypertension is the commonest presentation in children presenting in the occlusive stage ${ }^{12}$. However, this sequential presentation is likely to occur in a minority of patients because the disease is recurrent, leading to coexistence of various stages. Further, there can be activity during chronic illness, not all patients manifest the acute stage, and some patients present in chronic stage only. A variable interval (months to years) may separate acute stage from occlusive stage, during which vascular insufficiency develops ${ }^{1}$. TA has been rarely recognized in small children ${ }^{7,12-17}$, and tends to have a more aggressive course in children. In two series, the mortality rate was $35 \%-40 \%$ by five years ${ }^{13,18}$. Therefore, in very young children, diagnosis is frequently made postmortem. In our case, TA presented a very aggressive clinical picture.

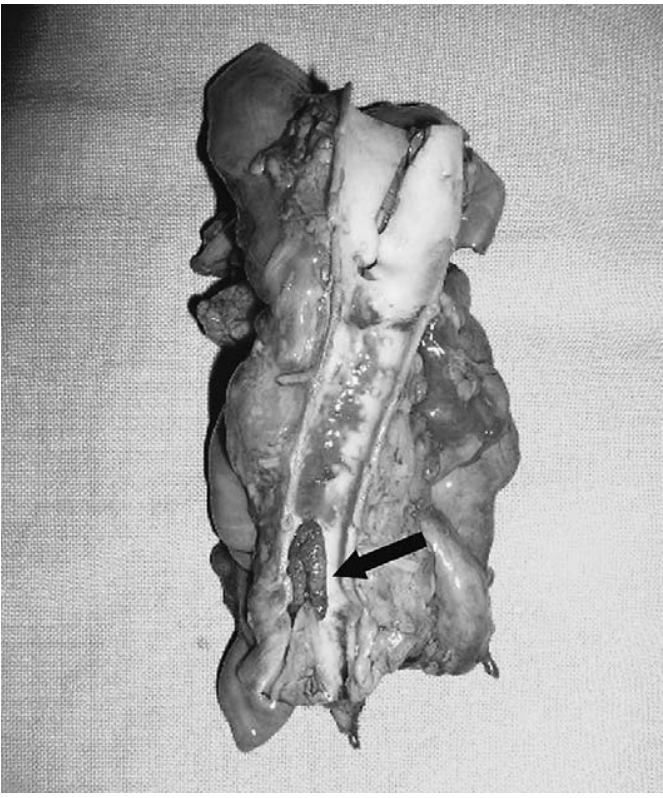

Fig. 2. Thrombus (arrow) at the level of distal aorta penetrating both iliac arteries.

\section{Case Report}

A 3.5-month-old male child arrived at $7.00 \mathrm{pm}$ with suspected acute abdomen and lower extremity thrombosis. Upon admission, he was pale, afebrile, calm and tachypneic. Tachycardia was 190 beats/minute. Blood pressure on the right and left arms was $87 / 58$ and $91 / 60 \mathrm{~mm} \mathrm{Hg}$, respectively. Lower extremities were cold, cyanotic, with weakened pulses over femoral arteries. His body weight was $5300 \mathrm{~g}$. Within one month prior to admission, he had otitis, maculopapular rash on his arms and legs, and he did not gain any weight. His family history confirmed atopy (neurodermitis and bronchial asthma).

Laboratory investigation revealed mild microcytic, normochromic anemia; white blood cell count 17,200x10 $/ \mathrm{L}$; C-reactive protein $43.6 \mathrm{mg} / \mathrm{L}$; thrombocytosis $\left(897 \times 10^{9} / \mathrm{L}\right)$; differential blood count shifted to the left (48\% neutrophils, $19 \%$ nonsegmented neutrophils, $5 \%$ metamyelocytes and $2 \%$ myelocytes) with some toxic granulation neutrophils; biochemical blood parameters were within the reference values, except for hyperglycemia; coagulation studies were within the normal limits; elevated levels of D-dimers (586 up to 1864); mild antithrombin III deficiency (0.69); protein $\mathrm{C}$ and $\mathrm{S}$, activated protein $\mathrm{C}$ resistance, plasminogen activator inhibitor-1 and lupus anticoagulant were 


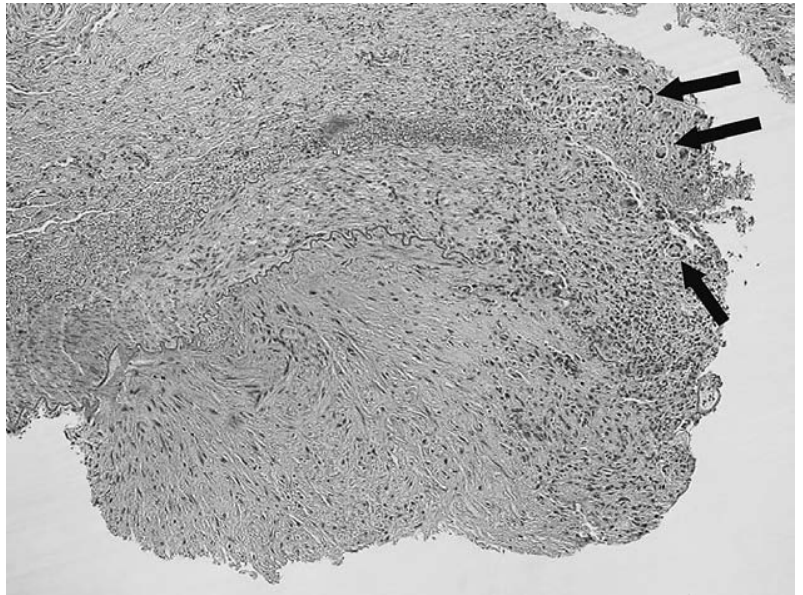

Fig. 3. Active Takayasu's aortitis illustrating destruction of the arterial media by mononuclear inflammation with giant cells (arrows) (hematoxylin, eosin, X200).

within the normal limits; proteinuria; hematuria; homocystine in urine was negative; cultures of cerebrospinal fluid, blood and urine were sterile.

Diagnostic testing started with ultrasound of the abdomen which did not show any pathologic signs. Normal morphology of heart leaflets was verified by ultrasound of the heart including appropriate blood flows, but due to significant tachycardia (up to 210/ min), ejection fraction of the left ventricle was estimated to be lowered and the width of the chamber dilated. Computed tomography angiography (CTA) verified occlusion of the distal section of the abdominal aorta (Fig. 1). During these investigations, the infant's symptoms worsened. The infant was now febrile and cyanosis of the lower abdomen, penis, scrotum and legs was present. The abdomen was distended and a bloody mucous stool was passed.

Thrombectomies at the level of common femoral arteries were performed. While thrombectomy on the right side was done, thrombosis on the left side reappeared, requiring repeat procedure. Ischemic changes then subsided, except for the big toe of the left foot. The infant was administered antibiotic, corticosteroid and heparin therapy in addition to antithrombin III and plasma. By the next day, ischemic changes on the left leg worsened again and thigh amputation was necessary. However, the infant died by 4.00 pm, 21 hours after admission.

Autopsy revealed thrombosis of the orifice of the upper mesenteric artery and distal part of the abdomi-

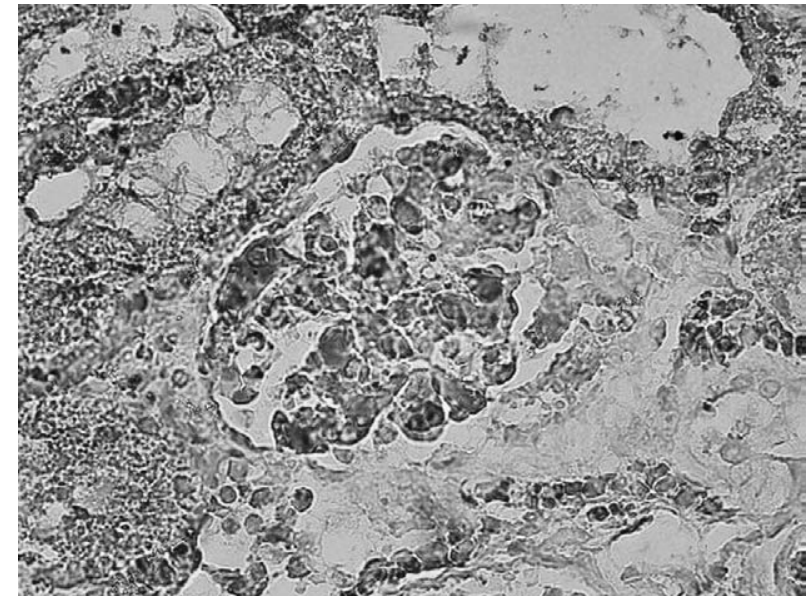

Fig. 4. Focal glomerulonephritis with segmental accumulations of immune complexes in the glomerulus (hematoxylin, anti-IgG, X1000).

nal aorta (Fig. 2). The latter had spread into both common iliac arteries (internal on the left side, and internal and external on the right side). Histopathologic findings revealed fibrous thickening of the aorta and its main branch walls, forming polypoid shapes within the lumen of the arteries. Clusters of granular tissue and granulomas with epithelioid cells and giant cells (Langhans and foreign body type) were verified (Fig. 3). Smaller granulomas with epithelioid cells and giant cells (mainly Langhans type) were also seen within pulmonary parenchyma. In enlarged and livid kidneys, focal segmental glomerulonephritis was histologically observed with clusters of immunoglobulin $\mathrm{G}$ complexes proved by immunohistochemical evaluation (Fig. 4). Ischemic ileitis, central necrosis of hepatocytes, and brain edema were also ascertained.

\section{Discussion}

In the initial stage of TA, symptoms are usually nonspecific, which seems to cause delay and errors in diagnosis. One study suggests that the time elapsed from the onset of symptoms to diagnosis is approximately 19 months in pediatric TA cases, as compared with 5 months in adults ${ }^{19}$. Laboratory diagnostics showed specific changes from normal but none of these pointed to a specific disease. Deficiency of antithrombin III led to suspicion of disseminated intravascular coagulation, especially due to the general condition of the patient and the clinical picture of lower 
extremities. However, antithrombin III deficiency can be present in kidney diseases and higher catabolism proteins $s^{20}$. Our attempt at treatment was surgical because the child presented in critical condition which demanded urgent intervention to try to save his life. CTA pointed to the need of emergency thrombectomy. There was exceptional intravascular coagulation that could not be controlled. Within several hours, attempts to save the infant's life, even to the extreme of thigh amputation, failed. It was not until autopsy results that the unexpected diagnosis of TA was made. The aggressiveness of thrombus dispersion was evident as the mesenteric superior artery showed thrombosis postmortem, although no thrombosis was present on initial CTA (Fig. 1).

Most studies on TA found in the literature deal with adult patients. Those studying children are scant ${ }^{1,8}$. $\mathrm{TA}$ is a rare vasculitis in pediatrics with important morbidity and mortality in children ${ }^{19}$. The youngest case presented in the literature was reported in 2013, presenting a 27 -day-old newborn with acute necrotizing aortitis ${ }^{21}$. One case report describes a 6-month-old infant, who improved after 10 months of vigorous immunosuppressant therapy, also stating that $75 \%$ of $\mathrm{pa}^{-}$ tients die within two years if left untreated ${ }^{22}$. A 4-month-old son of a known TA mother who died with features of the sudden infant death syndrome (SIDS) was histopathologically diagnosed with $\mathrm{TA}^{23}$, suggesting why reports on infant TA are so scant. Antihypertensive agents and steroid treatment along with angioplasty have been partially successful in controlling symptoms in $35.2 \%$ of cases $^{24}$. In order for this type of treatment to be successful, it is necessary to have enough time, which, unfortunately, our patient did not have.

\section{Conclusion}

The purpose of this case report is to remind physicians to consider TA as a possible diagnosis when encountering an infant with nonspecific diagnostic results. Our patient was not of the most commonly reported age or sex for TA, nor did he present with symptoms specific for TA; however, as this case report shows, this rare disease can present in infancy; our patient was only 3.5 months old. The fact that evidence for TA in infancy is scant in the literature may not indicate its absence bur rather the misdiagnosis of the disease. Awareness of TA and its nonspecific symptoms may enable physicians to treat younger patients effectively.

\section{References}

1. Gulati A, Bagga A. Large vessel vasculitis. Pediatr Nephrol. 2010;25(6):1037-48. doi: 10.1007/s00467-009-1312-9.

2. Kerr G. Takayasu's arteritis. Curr Opin Rheumatol. 1994;6 (1):32-8. doi: 10.1097/00002281-199401000-00006.

3. Kerr CS, Hallahan CW, Giordano J, et al. Takayasu arteritis. Ann Intern Med. 1994;120(11):919-29. doi: 10.7326/00034819-120-11-199406010-00004.

4. Eke F, Balfe JW, Hardy BE. Three patients with arteritis. Arch Dis Child. 1984;59(9):877-83. doi: 10.1136/adc.59.9.877.

5. Malčić I, Detoni P, Kniewald H, et al. [Takayasu arteritis and possible cardiology repercussions in the childhood]. Reumatizam. 2015;62(2):22-6. (in Croatian)

6. Ladhani S, Tulloh R, Anderson D. Takayasu disease masquerading as interruption of the aortic arch in a 2-year-old child. Cardiol Young. 2001;11(2):244-6. doi: 10.1017/S104795110 100021X.

7. Aypar E, Celebi-Tayfur A, Keser M, et al. Takayasu arteritis in a 4-year-old girl: case report and brief overview of the pediatric literature. Turk J Pediatr. 2012;54(5):536-9

8. Terreri MT, Clemente G. Developments in large and midsize vasculitis. Rheum Dis Clin North Am. 2013;39:855-75. doi: 10.1016/j.rdc.2013.08.002.

9. Jain S, Sharma N, Singh S, Bali HK, Kumar L, Sharma BK. Takayasu arteritis in children and young Indians. Int J Cardiol. 2000;75:S153-7. doi: 10.1016/S0167-5273(00)00180-7.

10. Hahn D, Thomson PD, Kala U, Beale PG, Levin SE. A review of Takayasu's arteritis in children in Gauteng, South Africa. Pediatr Nephrol. 1998;12(8):668-75. doi: 10.1007/s0046700 50526.

11. Sano K. Takayasu disease - pulseless disease. Brain Nerve. 2008;60(1):31-5.

12. Cakar N, Yalcinkaya F, Duzova A, et al. Takayasu arteritis in children. J Rheumatol. 2008;35(5):913-9.

13. Morales E, Pineda C, Martínez-Lavín M. Takayasu's arteritis in children. J Rheumatol. 1991;18(7):1081-4.

14. Mcculloch M, Andronikou S, Goddard E, et al. Angiographic features of 26 children with Takayasu's arteritis. Pediatr Radiol. 2003;33(4):230-5. doi: 10.1007/s00247-002-0817-1.

15. Maksimowicz-McKinnon K, Clark TM, Hoffman GS. Limitations of therapy and a guarded prognosis in an American cohort of Takayasu arteritis patients. Arthritis Rheum. 2007; 56(3):1000-9. doi: 10.1002/art.22404.

16. Ozen S, Bakkaloglu A, Dusunsel R, et al. Childhood vasculitides in Turkey: a nationwide survey. Clin Rheumatol. 2007; 26(2):196-200. 
17. Hijazi R, Chandar J, Nwobi O, Muneeruddin S, Zilleruelo G, Abitbol CL. Renal manifestations in toddlers with Takayasu's arteritis and malignant hypertension. Pediatr Nephrol. 2009; 24(6):1227-30. doi: 10.1007/s00467-008-1088-3.

18. Aluquin VP, Albano SA, Chan F, Sandborg C, Pitlick PT. Magnetic resonance imaging in the diagnosis and follow up of Takayasu's arteritis in children. Ann Rheum Dis. 2002;61(6): 526-9. doi: 10.1136/ard.61.6.526.

19. Castellanos AZ, Campos LA, Liphaus BL, Marino JC, Kiss MH, Silva CA. Takayasu's arteritis. An Pediatr (Barc). 2003; 58(3):211-6. doi: 10.1016/S1695-4033(03)78039-4.

20. Kauffmann RH, Veltkamp JJ, Van Tilburg NH, Van Es LA. Acquired antithrombin III deficiency and thrombosis in the nephrotic syndrome. Am J Med. 1978;65(4):607-13. doi: 10.1016/0002-9343(78)90848-3.
21. Hejazi A, Hosseini M, Bahrani M. Acute necrotizing large vessel arteritis in a newborn: a case report and review of the literature. Am J Forensic Med Pathol. 2013;34(2):127-9. doi: 10.1097/PAF.0b013e31828d69da.

22. Kohrman MH, Huttenlocher PR. Takayasu arteritis: a treatable cause of stroke in infancy. Pediatr Neurol. 1986;2(3): 154-8. doi: 10.1016/0887-8994(86)90007-X.

23. Mosonyi A, Ludmany E, Matos L, Czeizel E. Genetic counseling in a case of Takayasu arteritis. Orv Hetil. 1996;137(11): 585-7.

24. Muranjan MN, Bavdekar SB, More V, Deshmukh H, Tripathi M, Vaswani R. Study of Takayasu's arteritis in children: clinical profile and management. J Postgrad Med. 2000;46(1):3-8.

Sažetak

\section{AGRESIVNI OBLIK UZNAPREDOVALOG TAKAYASUOVA ARTERITISA U DOJENAČKOJ DOBI: PRIKAZ SLUČAJA}

\section{R. Pavić, R. Blažeković, D. Divković, K. Marjanović i M. Sipl}

Takayasuov arteritis (TA) zahvaća aortu i njezine ogranke. Imunosupresivi su obično terapija ove bolesti, dok je kirurško liječenje opisano samo u akutnim slučajevima. U literaturi ne postoji puno podataka o TA u dojenačkoj dobi. Nespecifični simptomi na početku bolesti otežavaju postavljanje dijagnoze i povećavaju stopu smrtnosti. Bolesnik opisan u ovom prikazu slučaja je najmlađi ikad objavljen u literaturi. Tri i pol mjeseca star dječak je imao cijanotične obje noge, tahikardiju i manjak antitrombina III. Kompjutorizirana tomografija angiografija (CTA) je pokazala trombozu distalne aorte i obiju ilijačnih arterija. Trombektomija je odmah zatim učinjena na razini obiju zajedničkih femoralnih arterija. Daljnje komplikacije su zahtijevale natkoljeničnu amputaciju lijeve noge. TA je dijagnosticiran nakon smrti bolesnika pri obdukciji s vidljivom trombozom distalne aorte i njezinih ogranaka, gornje mezenterične arterije koja nije bila zahvaćena na ranije učinjenoj CTA te glomerulonefritisom i plućnom parenhimatoznom granulomatoznom infiltracijom.

Ključne riječi: Takayasuov arteritis; Dojenče; Tromboza; Imunosupresivna sredstva; Prikazi slučaja 